\title{
THE ROLE OF EARLY CHILDHOOD TUTORS IN OPTIMIZING THE EARLY CHILDHOOD LEARNING ENVIRONMENT AT PAUD NOOR RAKHMAH BANDUNG
}

\author{
Ria Maryana \\ IKIP Siliwangi \\ riamaryana26@gmail.com
}

\begin{abstract}
Non-formal Early Childhood is a symbol of the council school when viewed from the tuition fee that is voluntary and not mandatory, so do not imagine this school has the good facilities. In terms of places, early childhood doesn't have own building, mostly using village hall or other public facilities such as mosques or musholla. This limitation also has an impact on early childhood space for learning. Children cannot play and move freely and develop themselves. The environment of learning should be a lot of attention, the environment will affect the learning process and learning outcomes for children. This research is qualitative research with study descriptive. This research is based on the problem of various conditions of environmental management learning in Early Childhood Education (PAUD) Noor Rakhmah related to facilities and infrastructure. Tutors have an important role in optimizing the management of early childhood learning environments. The purpose of this research is to obtain data that is: (1) The planning process conducted by Tutor PAUD Noor Rakhmah in optimizing the early childhood learning environment. (2) The implementation process conducted by Tutor PAUD Noor Rakhmah in optimizing the early childhood learning environment. (3) The evaluation process conducted by PAUD Noor Rakhmah Tutor on the utilization of early childhood learning environment.
\end{abstract}

Keywords: Environmental Management Learning, Early Childhood

\section{INTRODUCTION}

Education is an effort to help reach the maturity of people. This effort demands a process to be achieved. Without such a process, the change will not happen also the goal will not be achieved. Education should be instilled early on, the importance of Early Childhood Education (PAUD) is supported by research on children's brain intelligence consisting of 100 billion brain cells that must be stimulated (Direktorat PADU, 2002: 9). These brain cells need the right stimulation to connect together with the dense network as a sign of an intelligent child. The educational stimulation provided and parenting patterns, as well as educators, are one determinant for optimizing the use of this brain.

Education environment is divided into three, namely education in the family environment, school environment, and community environment. Because of education is basically not necessarily in the form of formal education just like in the school environment, but non-formal education such as education in the family and community is also very supportive (Dyah Fifin Fatimah, 2016). It is also disclosed in Undang- 
Undang No. 20 Tahun 2003 on the National Education System Article 28 on Early Childhood Education which states that:

1. Early Childhood Education is held before the level of basic education.

2. Early Childhood Education can be organized through formal, non-formal and/or informal education channels.

3. Early Childhood Education in the formal education path is the form of kindergarten (TK), Raudlatul Athfal (RA), or other forms.

4. Early Childhood Education on non-formal education channels is the form of Play Groups (KB), Day Care (TPA), or other similar forms.

5. Early Childhood Education on an informal education pathway is a family or educational education organized by the environment.

Based on the grouping of education units above, it can be seen that in addition to formal education, non-formal education also plays a very important role. To implement early childhood education requires a learning environment. Certainly, in this case, teachers or tutors have an important role in managing a learning environment. The role of the teacher as an inspirational learner, inspiring the teacher to be able to describe himself as an inspirational person (inspiring teaching for students), learning and learning activities can produce variations mind, imagination, creativity and new ideas (Ar-Raisul Karama Arifin, 2014). The learning environment should be more attention because of through the environment will affect the learning process and learning outcomes for children. It takes the management of a good learning environment that children can grow and develop according to the stage of its development. Management is the set of management, teaching is a process of teaching and learning. Thus, the management of teaching can be defined an attempt to organize or manage the teaching and learning process in accordance with the concept and principles of teaching in order to achieve the goal of teaching effectively and efficiently (Rosyid Ridho, 2015).

Anwar (2009: 10) argues that "environmental stimuli will affect the formation of relationships between brain cells that coordinate various aspects of development, motor development, cognitive, language, social, emotional and spiritual. If environmental stimulation is lacking, unstimulated brain cells will gradually be eliminated". Learning is an activity that requires a high concentration, a place that comfortable learning environment makes it easier learners for concentrate. By preparing the right environment, learners will get better results and can enjoy the learning process that learners do. Gagne (Mariyana, 2005: 10) states that "events in the environment will greatly affect the child's learning outcomes". A systematic, planned and orderly environment will help get the appropriate response from each child. This is confirmed by Semiawan (Mariyana, 2005: 10) "The better an environment is prepared the higher of positive response we can take from the children logic". Thus, there will be an increasingly relevant impact, tutor and parent are expectations too.

Children born in the world in a state of incomplete, because of all instincts, physical functions and spirituality have not been developed perfectly. Therefore the human child has a long possibility for freely develop. What is meant by freedom developing here is to be able to maintain his life and to be able to adjust to his environment (Murni, 2017) 


\section{METHOD}

The research method used is a descriptive method, with a qualitative approach. Data collection techniques used are interview and observation techniques, data analysis techniques with data descriptions, data reduction and conclusions. Sources of data in this study are four people informants consisting of one Early Childhood Education tutor in Noor Rakhmah, one headmaster and two parents of students.

\section{RESULTS AND DISCUSSION}

\section{A. Tutor's planning process of the management of early childhood learning environment}

Planning in managing a learning environment must be implemented, so the learning objectives can meet various aspects of child development. According to Sudjana (1992: 38) "planning includes a series of activities to determine the general goals and specific goals". The purpose of the management of the learning environment is to stimulate children into the learning environment, to facilitate aspects of child development, and to provide opportunities for children move (Mariyana, 2005: 17-19). Children are sensitive to receive all stimuli, namely during the period of physical and psychic functions are ready to respond to all stimuli provided by the environment. Thus, the environment as an element that supplies or provides some stimulus needs to get serious attention. Special planning and selection are required in order to provide a suitable and necessary environment for the child. The accuracy of the environment provided will have an effect on the process and results in the child's behavior either directly or indirectly (Susilowati, 2014)

Based on results, the planning process interview conducted by the tutor in the management of the learning environment in Early Childhood Education (PAUD) Noor Rakhmah is by preparing the theme of learning and preparing components that will be used. Tutors should consider what components will be applied to the learning environment. Suitable components in the learning environment will affect the child's learning outcomes, through appropriate compositions such as decoration, drawing, color selection, and other components that can make the child focus on learning activities. If the children bored with the learning environment, tutors should have a specific plan strategy for additional. Creating a new environment for children is one way to attract children into the learning environment. It will find a new thing to learn a new activity in the learning environment.

The planning process conducted by tutor in Early Childhood Education (PAUD) Noor Rakhmah to develop the children potential is by preparing various components that can stimulate the sensory, motoric, cognitive and moral development of children. Child development and child learning are explained by the developmental theory of Jean Piaget, which over the last few decades has greatly affected the practice of preschool or pre-school education. According to this theoretical view, children develop cognitively through active involvement in their environment; each stage of development is intertwined and integrated with each other (Susilowati, 2014). Things that are prepared by the tutor is through learning media such as educational game tools, and utilize the existing components in the environment to be used as a source of learning. In addition, the learning environment tailored to the child's developmental stage that refers to Permendiknas No 58 Tahun 2009. Level of child development achievement by Permendiknas No 58 Tahun 2009 organized by age group of children: $0-<2$ years; $2-<4$ 
years; and $4-\leq 6$ years. Levels of child development achievement include religious and moral values, motor, cognitive, language, and social-emotional.

The planning process is done simultaneously with the preparation of lesson plan (RPP), every day tutor designing an environmental component based on the theme of learning. In addition, tutors involve parents in planning the learning environment. Parents also prepare the components that will be used in the learning environment.

The learning environment is not only about the physical, but the efficiency of the learning environment, and how to build the atmosphere in the learning environment that the learning process can run well. The learning environment that is built must be able to provide opportunities for activity and creativity in children freely to develop the various potentials it has as well as aspects of its development.

\section{B. The Implementation Process Performed by Tutor in Environmental Management of Early Childhood Learning}

Implementation is an application of the results of the design that has been determined. Teachers are expected to facilitate children by creating a pleasant environment that children can always keep the title as an active agent (Hidayatulloh, 2014). For combining the various components In managing a learning environment requires a high skill and creativity. According to Mariyana that (2005: 130-138) "The ability of a tutor is needed in creating and managing the learning environment", including:

1. Build and manage the learning environment.

2. Organize and create a learning environment.

3. Maintain the safety of the learning environment.

4. Maintaining the health of the learning environment.

5. Competence in communication relations.

The implementation process of managing the learning environment is tailored to the concept. According to Mariyana (2005: 130) "Establishing and managing a learning environment for children requires the ability of teachers to create a conducive atmosphere that children can learn with fun". Based on the results of interviews, the implementation carried out in establishing and managing the learning environment to create a conducive atmosphere for children is to pay attention to security, comfort, tidiness, and cleanliness. The child feels comfortable with the learning environment. The learning environment should be created that make children feel at home.

Organize in the learning environment is made children focused on the learning given. Structuring the learning environment in Early Childhood Education (PAUD) Noor Rakhmah tailored to the child's tastes and interest. According to John Dewey that (Yus, 2011: 6-7) "Children's interests become important to learn. This interest is a reference to determining a topic of learning". The statement revealed that the arrangement of the learning environment in Early Childhood Education (PAUD) Noor Rakhmah tailored to the theme of learning. The learning environment should be able to create a fun learning environment. Such as an atmosphere of lively learning interaction, developing appropriate media, utilizing appropriate learning resources, motivating children to participate in the learning process, making the learning environment conducive. Creating a learning environment in Early Childhood Education (PAUD) Noor Rakhmah is not done every day, it is done in accordance with the needs of the theme of learning. The learning 
environment is usually done one hour before the learning begins. But, if the components that will be used a lot and require a lot of time, then the management of the learning environment is done one day before the learning, which is at home, together with the preparation of lesson plan for the next day.

According to Mariyana (2005: 131) "To organize and create a pleasant learning environment, the ability to choose, separate and put learning components together". This is related to the essence of the learning to aspects of child development. All components used must have meaning for the child. Organize and create a learning environment done by the tutor in accordance with the predefined learning theme. According to Yus (2011: 84) "Theme determination based on child characteristics and learning materials. In addition, the tendency should make children's interest is also the basis for the determination of the theme". Through the theme of learning is determined what media will be used later. Components that are used not only in the classroom, but tutors utilize the conditions around the school environment that can be used as media/tools in the learning process.

Media commonly used in Early Childhood Education (PAUD) Noor Rakhmah is educational game tools, print media, electronic media and utilize the existing potential around such as used goods and natural resources around.

The learning environment is a place where children learn many things. The safety of the learning environment is an important foundation for all teachers to have. Before all learning activities begin, the teacher must ensure that each learning environment safe, Mariyana (2005: 132). The tutor exercises environmental control through the separation of objects that may endanger the child as well as objects that do not harm the child. Also according to Mariyana (2005: 137) "A healthy learning environment affects child health. The maintenance of learning media and familiarize children to wash hands after using the media learning is one way to encourage children to do healthy living habits is a good activity that they usually do in the learning environment".

Managing the learning environment not only creates the appearance, but also the social relationships (1) in the learning environment need to be built. In addition to the interactions that occur (2) the learning environment between tutors and learners, tutors should also be able to communicate with the school and parents of learners in managing the learning environment. In this case, tutor's will collaborate with parents and the school to create a good learning environment in Early Childhood Education (PAUD) Noor Rakhmah. Activities are undertaken in the form of parenting programs. Parenting activities carried out the making of learning media which later became school inventory. The activity is conducted once a month. By means of these activities components in a learning environment can be fulfilled. Parents, schools, and tutors should help each other optimize the management of the learning environment.

\section{The process of evaluation is conducted by Tutor in the management of early childhood learning environment.}

The condition of educational outcomes is strongly influenced by the various components. The position and role of teachers are often regarded as the most responsible component of the education system. The success of tutors in managing the learning environment can be seen from the results that have been achieved based on the goals that have been determined. According to Sudjana (1992: 39) assessment related to the activities of collecting, processing and presenting information to be input 
into decision making. The assessment results are feedback on the success of decisionmaking. The evaluation process conducted by the tutor is to see the results that can be felt directly about the management of the learning environment that has been created. In addition, the evaluation is conducted to see the impact on the management of the learning environment on aspects of child development (Sunhaji, 2014; Anwar, 2009)

The results of interviews as regards the evaluation process conducted by the tutor in the management of the learning environment that related to the results and impact. The tutor performs the evaluation paradigm by observing, asking questions, drawing, coloring for the child to see the child's learning outcomes. Changes as a result of the learning process can be shown in various forms such as changing knowledge, understanding, attitude, and behavior, skills and abilities, reactions, acceptance and other aspects of the individual (Sudjana, 2000: 28)

The management of the learning environment can be perceived directly by the child and the tutor. Through the management of the learning environment, children need not be forced to enter a learning environment. The ideal learning environment affects the learning outcomes of children. The changes it can be seen children become more focus on learning activities. If the place in learning environment makes children comfortable, so the results of learning would be better. Through the management of the learning environment, the learning process runs effectively and efficiently, both in terms of time and appropriately to the content of the learning given. Good preparation and arrangement make it easy for tutors in the learning process.

The impact out of the management conducted by the tutor was able to develop aspects of child development, through various components created by the tutor is able to stimulate the development of children. The physical environment created makes the child interested to enter into the learning environment. Through the environment, the stimuli are given able to develop aspects of child development.

The management of the learning environment created in early childhood Noor Rakhmah has an impact on child development aspects, including:

\section{Sensory Development}

The learning environment affects the child's sensory development, through the objects they see and they feel capable of stimulating the senses of the child. Early Childhood Education (PAUD) Noor Rakhmah used the surrounding environment as a learning resource such as plants, sand, stone, etc. can develop sensory in children.

\section{Motor Development}

The environment will stimulate the physical growth of children, through the use of open land around the Early Childhood Education (PAUD) Noor Rakhmah able to provide opportunities for children to develop muscles, by running, jumping, tiptoe, and perform other movements.

\section{Cognitive Development}

The environment that is able to develop the cognitive aspects of the child is created by the tutor, through the various components that exist in the learning environment. The child's ability to use his brain is thoroughly stimulated through remembering, grouping, recognizing and selecting activities. Such as the introduction are shapes, colors, patterns and other general knowledge. 
4. Moral Development

Moral development applied in Early Childhood Education (PAUD) Noor Rakhmah more emphasized to religion. Through the learning environment created, the use of the mosque as a place of learning is done by the tutor. Every day children are taught to perform prayer activities before learning begins. Through a built learning environment that encourages them to interact, ask, tell stories about the new environment they find.

\section{CONCLUSION}

Based on the results of data analysis, It has been suggested that tutors in Early Childhood Education (PAUD) Noor Rakhmah who became research samples is a good performer in their role managing on learning environment. Even though they didn't have a high education background, they are able to manage a learning environment based on their experiences. Management of the learning environment needs to be done to facilitate the learning process. In the process of teaching and learning, the environment is an influential learning resource in the process of learning and development of children. The learning environment is the place of learning activities, the environment that is the source of learning has an influence on the learning process.

1. Planning Process To Manage An Early Childhood Learning Environment by Tutor. Preparing learning resources related to the arrangement of the learning environment, selecting suitable media and adapted to the existing theme by the tutor, so the management of the learning environment can be done to meet the needs of the child. Through the designed planning can facilitate the tutor in creating a learning environment. The planning process is implemented every day together with the preparation of lesson plan (RPP). Parents are also involved in the planning process to create a good learning environment.

2. Implementation Process In Managing the Tutor Toward Environmental Management Learning Early Childhood

Before the learning begins, create a learning environment by the tutor. They have to create a conducive learning environment, so the children feel safe and comfortable. The process of managing the learning environment is implemented through the arrangement of learning environment or area state. Each component applied by the tutor in the learning environment is chosen based on the child's need to develop the sensory, motor, cognitive and moral aspects of development. Selection of media as a learning resource selected tutors tailored to the theme of learning. Media used in the form of print media, electronic media, educational games, and utilization of the surrounding environment to be a good source of learning for children. Implementation in managing the learning environment should always pay attention to environmental control for safety and cleanliness in the learning environment it can be maintained.

That is important elements such as tutors, school, parents can be involved, the management of learning environment can work well. The ability of tutors in establishing cooperation with the school and parents is able to optimize the management of the learning environment well. Disadvantages that exist in the learning environment such as facilities and infrastructure can be met through the cooperation. Tutors, the school, and parents together are doing activities to facilitate the learning environment in Early Childhood Education (PAUD) Noor Rakhmah. 
3. Evaluation processes conducted by Tutor in the management of early childhood learning environment

The evaluation processes undertaken by the tutor aims to see results that can be felt directly, such as an impact on the child's development after managing the learning environment is made. The evaluation process is done by observing and conducting $Q$ \& A activities. Success can be seen from changes in children's attitude and learning outcomes of children after applied learning environment. The management of the created learning environment is able to develop the sensory, motor, cognitive and moral aspects of the child's development. For example from the sensory aspect of the child can use all the senses by way of learning media such as plants, from the motor aspect the child is able to use all his muscles to run, utilizing open land around. Early Childhood Education (PAUD) Noor Rakhmah, from the cognitive aspect of the child, is able to use the whole brain as when receiving information, and from the moral aspect of the child is able to perform worship activities such as prayer. These things can be developed if only the existing learning environment is able to stimulate all aspects of child development.

\section{REFERENCES}

Anwar. (2009). Pendidikan Anak Dini Usia (PADU) Panduan Praktis Bagi Ibu dan Calon Ibu. Bandung: Alfabeta.

Aqib, Z. (2011). Pedoman Teknis Penyelenggara PAUD (Pendidikan Anak Usia Dini). Bandung: Nuansa Aulia.

Ar-Raisul Karama Arifin, N. A. (2014). Peran Pendidik PAUD dalam Mengimplementasikan Pendidikan Karakter Melalui Metode Pembelajaran Sentra dan Lingkaran. Jurnal Psikologi Pendidikan dan Perkembangan Volume 3 No.3 , 188-198.

Direktorat Pendidikan Anak Usia Dini. (2005). Pentingnya Pendidikan Anak Usia Dini. Jakarta: Depdikbud.

Dyah Fifin Fatimah, N. R. (2016). Pola Pengelolaan Pendidikan Anak Usia Dini di PAUD Ceria Gondangsari Jawa Tengah. Jurnal Manajemen Pendidikan Islam Volume 1, Nomor $2,247-273$.

Hidayatulloh, M. A. (2014). Lingkungan Menyenangkan dalam Pendidikan Anak Usia Dini: Pemikiran Montessori. Jurnal Pendidikan Islam , 139-154.

Mariyana, R. (2005). Strategi Pengelolaan Lingkunga Belajar Di Taman Kanak-Kanak. Jakarta: Departemen Pendidikan Nasional.

Mulyono, D. (2017). Menegaskan Karakter Pendidikan Nonformal. Empowerment, 1(1).

Murni. (2017). Perkembangan Fisik, Kognitif, Dan Psikososial Pada Masa Kanak-Kanak Awal 2-6 Tahun. Jurnal Anak Usia Dini Vol III , 19-32.

Rosyid Ridho, M. d. (2015). Pengelolaan Pembelajaran Anak Usia Dini (PAUD) di KB "Cerdas" Kecamatan Sukorejo Kabupaten Kendal. Jurnal Penelitian Humaniora

Vol $16,59-69$.

Sudjana, D. (2000). Pendidikan Luar Sekolah, Wawasan, Sejarah Perkembangan, Falsafah, Teori Pendukung, Asas. Bandung: PT. Remaja Rosdakarya.

Sudjana, D. (1992). Pengantar Manajemen Pendidikan Luar Sekolah. Bandung: PT. Nusantara Press-Yayasan Islam Nusantara.

Sunhaji. (2014). Konsep Manajemen Kelas dan Implikasinya Dalam Pembelajaran. Jurnal Kependidikan , 30-46. 
Susilowati, R. (2014). Strategi Belajar Outdoor Bagi Anak PAUD. Jurnal Inovasi Pendidikan Vol 2 , 65-82.

Yus, A. (2011). Model Pendidikan Anak Usia Dini. Jakarta: Kencana Prenada Mediagroup. 